\title{
Erratum zu: Aktuelle Raketen und zukünftige Trägersysteme
}

\section{Erratum zu:}

Kapitel 4. In: S. Piper, Space - Die Zukunft liegt im All, https://doi.org/10.1007/978-3-662-59004-1_4

Folgende Änderung wurde ausgeführt:

Seite 65: Der Satz „In nicht allzu ferner Zukunft könnte auf diese Weise der Dream Chaser gestartet werden." wurde entfernt. 